\title{
MANUFACTURER'S LIABILITY
}

\section{A. R. THOMPSON*}

Professor Thompson discusses the need for a viable classification system for manufacturer's liability to facilitate the lawyer's keeping abreast of modern developments in this area of the law. The subject is analyzed by examining the distance the final purchaser in the distributive chain is from the manufacturer; the problems the purchaser encounters in relation to the goods themselves, and certain collateral matters; what the purchaser desires as his remedy; and what remedy is actually available in either contract or tort; and the effect of exclusion clauses on the remedies available to the purchaser. The article examines the case authorities and Professor Thompson shows how contract and tort requirements are merging into a new field of manufacturer's liability. The article concludes that the consumer is in a good position with regard to the doctrinal aspects of the law in this area, that lawyers and judges are playing a dynamic role in modernizing the law through the cases, but that law reform is still necessary on the procedural and institutional side.

Lawyers are as much classifiers of discreet bits of information as are botanists or butterfly collectors, or, for that matter, as are programmers of computers. Quite automatically the lawyer analyzes the data which his clients feed to him and sorts out the relevant facts into classifications -this is a tax problem-that raises a question of property law. If he does a good job of classifying-that is, of narrowing issues from the general to the particular-he may make a confident prediction about the outcome of certain actions, and can advise his client well. Thus, his classifying leads him to a particular decided case, or to a statutory provision or regulation which covers the situation, or to some previous client experience that offers a solution.

These classifications, at least in the common law systems, are not given a priori, but are sought after and, if necessary, invented by judges, text writers, digest editors and by practising lawyers. It is the aim of these gentlemen to provide an organized and logically structured body of law out of the myriad factual situations presented for legal processing. The beginning point in the process is the fact situation.

In these times we are only too conscious of a rapidly changing environment, and therefore, of rapidly changing fact situations. In such an environment we must expect an increasing need for new classifications and that the classifying process will be under great strain to keep abreast of the times. Your professional responsibility, if you are a practising lawyer, is to keep your classification apparatus as serviceable and up-to-date as possible. I understand the purpose of this lecture to be to help you in doing so, for the academic lawyer has the advantage over you in this respect.

The topic "Manufacturer's Liability" illustrates as well as any topic could the need to keep up with the times. One has only to turn the pages of standard reference works like Halsbury, or the English and Empire Digest or the Canadian Abridgement to find that the topic is not even listed. In the years 1953 to 1957 I served as the General Editor of Butterworth's Ontario Digest and in the course of this work procesesd some 30,000 Ontario cases into some 125 separate titles. I was quite

- LL.B. (1948), LL.M. (1954), J.S.D. (1967), Professor, Faculty of Law, University of British Columbla. 
conscious of a need to innovate at that time since the post-war period was already beginning to show new initiatives and new directions, but my innovative urge emboldened me to include the title "Manufacturer's Liability" merely as a minor sub-heading in the title "Negligence", where the Donaghue and Stevenson cases would be placed. Now there are two and three-volume text books on "Products Liability", and there are Consumer Protection bureaus in all levels of governments. The lead has come from the United States in this new field, but Canadian developments are not far behind.

It is almost a quarter of a century since I started studying law. Our commercial law course in 1946 was an annotation of the Bills of Exchange Act and of the Sale of Goods Act. For the former we used McLaren on Bills and Notes. Section by section through the Act, this text gave examples of bills which were valid and bills which were not, of notice of dishonour which was correctly given, and notice of dishonour which was defective. If one had an excellent memory, and should his future clients present problems about bills which matched those featured in the text book, the course was excellent. The Sale of Goods course was based on Chalmer's Annotated Sale of Goods Act, and on that great textbook, Benjamin on Sales. I say great, for not only its contents but the circumstances of its writing, represented extraordinary achievement, and the book, for me, marks a high point in English legal writing. Benjamin was foremost a barrister, and his text book, like his briefs, placed every decided case into its proper place in a carefully and logically structured presentation of the law of sales. In fact, such writers were so superbly successful, and their writings were so authoritative, that English lawyers and especially colonials like Canadians and Australians, have been intimidated by them ever since, and are only now gaining confidence in their ability to make new formulations to serve new times and places. We law students in 1946 read scores of cases about the sufficiency of a memorandum in writing to satisfy the Statute of Fraud provisions of the Sale of Goods Act, and as to whether there was a "deposit or acceptance and actual receipt of the goods" so as to take the case out of the statute (Benjamin has 140 pages in his text book on Statute of Frauds cases). We also read scores of cases about the passing of property in goods, and, in the process, learned about the sale of jute, kapok, and English corn, and about charter-parties and CIF contracts-at least enough to know that they all had little to do with the Canadian prairie scene of the 1940's. We also learned enough about the passing of property under a contract of sale to realize just how little abstract theorizing about property or title in goods had to do with day-to-day dealings of buyers and sellers.

When I started teaching at the Alberta law school in 1950, the situation was little changed. I taught a course called Bankruptcy and Bills. There was also a course on Sales and Suretyship, and later I taught this course, too. It came to me with an inherited case list, and this list, which I slavishly taught for several years, was as rooted in the 19th Century as was the course I took at the Manitoba law school in 1946.

Now, the English text books and cases have disappeared from the law schools, and casebooks prepared by Canadian law teachers have taken their place. The new approach is a functional study of Commercial law. One writer in the United States (Hawkland) has produced 
what he calls a Transactional Guide to Commercial Law. If I may be profound for a moment, I see this movement as merely a new look at the facts. We've shaken off the spell-binding effect of the great English commercial statutes and writings of the last century, and are now taking a fresh view of the practices of marketing goods and services. In many cases, the facts are not all that new-mass advertising, for example, has been around for a long time. What is new, is that lawyers, judges and law school professors are prepared to look afresh, and in the process, to move rapidly towards new solutions. If you don't believe me when I claim an enlivened and searching profession, just consider a few examples in Canada:

(i) The movement towards professional, institutionalized law reform.

(ii) The strength of the Canadian law schools-there are more academic lawyers around than ever before, and if you don't credit them with much practical sense, at least they're catalysts towards a more aware profession.

(iii) Judges who are prepared to take bold steps in reshaping the law, and, obviously, lawyers who are prepared to offer fresh arguments to encourage these judges to take new initiatives.

Many of these steps are proceeding in the commercial law. Following the lead in the United States, we in Canada will soon be refurbishing the 19th century commercial statutes into modern garb. The Commercial Law Subsection of the Canadian Bar Association has a special sub-committee at work on Personal Property Security Legislation. Next will be the law of Sales. We cannot long remain behind the Uniform Commercial Code developments in the United States.

After this long introduction to the subject, may I now present a functional analysis of the subject of manufacturer's liability. In calling the analysis "functional", I wish to signify that my analysis will proceed, not from a priori legal categories but from the functions of manufacturing and marketing goods.

\section{FUNCTIONAL ANALYSIS OF MANUFACTURER'S LIABILITY \\ I The Client \\ II The Client's Problem \\ III What the Client Wants \\ IV What Can Be Done About It \\ V Effect of Attempts to Exclude Liability}

(1)

Purchaser for use (e.g. consumer, processor, etc.)

\section{The Client}

Purchaser for re-sale (e.g. wholesaler, dealer)

\section{The Client's Problems}

\footnotetext{
Relating to the Goods Themselves Non-delivery Misdelivery Wrong quantity Defective quality, etc. (generally, covered by Sale of Goods Act)
}

Loss of profits Injury to other property Personal injury
Consumer or Bystander
(4)

Remote Bystander 


\section{What the Client Wants}

(1)

Rescission

Recovery
of money
paid

Escape from

future

obligations

Rejection

of Goods
(2)

Performance

Delivery

Repair

Replacement
(3)

Damages

Relating to

Goods themselves

Consequential

loss
(4)

Relief from

Financing

Obligations

\section{What Can Be Done About It}

Items

Contract

Tort

$\begin{array}{ll}\text { A. I(1) }+ & \begin{array}{l}\text { Innocent misrepresentation, if } \\ \text { II(1) }+\end{array} \\ \text { III(1) } & \begin{array}{l}\text { not too loyd Fre. See Long v. } \\ \text { (Purchaser for }\end{array} \\ \begin{array}{l}\text { Rightful rejection of goods } \\ \text { Use-Defect }\end{array} & \begin{array}{l}\text { and notice of recission. } \\ \text { Total failure of consideration. }\end{array} \\ \text { in Quality } & \text { Tants recovery } \\ \text { of money) } & \end{array}$

B. I(2) $+\quad$ Loss of profits on resale may

II(2) +

III (3) (b)

(Wholesaler or

or may not be recoverable-

Hadley \& Baxendale-whether

dealer, loss

of profits on

resale, wants

damages)

C. $I(1)+$

II (2) +

III (3) (b)

(Purchaser

reasonably in contemplation.

Not likely to be applicable since it is difficult to find a duty not arising under the contract. If it were, loss of profits recoverable if a direct consequence, see below.

NA

for use, consequential

loss of profits,

wants damages)

Recoverable as in preceding section. Advisable to sue also in tort, see opposite column.

\begin{abstract}
In Fillmore's Valley Nurseries Ltd. v. North American Cyanimid $^{2}$ recovery was awarded both in contract and in tort for negligence based on failure to test product adequately. Loss of profits recovery may be wider in tort than in contract, e.g., in contract recovery was limited to loss of profits on pansy crop destroyed by defective weed killer. In tort, recovery was extended to include loss of profits on other nursery stock because pansies happened to be the feature product and loss of pansy sales reduced sales of other nursery stock.
\end{abstract}

D. Generally speaking, when Client is a purchaser, the issues are the familiar ones arising under the Sale of Goods Act. In these cases the manufacturer is reclassified simply as a seller of goods. 


\begin{tabular}{|c|c|c|}
\hline Items & Contract & Tort \\
\hline $\begin{array}{l}\text { E. I (3) + } \\
\text { II (1) + } \\
\text { III(1) (3) } \\
\text { (Remote } \\
\text { purchaser, } \\
\text { defect } \\
\text { relating to } \\
\text { goods, wants } \\
\text { rescission } \\
\text { or damages) }\end{array}$ & $\begin{array}{l}\text { Client can claim only against } \\
\text { B, who must claim from C, } \\
\text { who has claim against man- } \\
\text { ufacturer. Privity of contract } \\
\text { rule prevails, see Smith v. } \\
\text { Ford Motor Co., " Haddad, } \\
\text { J.D.C. } \\
\text { Exception: an effective "guar- } \\
\text { antee" running between client } \\
\text { and manufacturer. } \\
\text { Possibility: In U.S. in certain } \\
\text { cases (e.g. automobile man- } \\
\text { ufacturers) there is an im- } \\
\text { plied warranty of reasonable } \\
\text { suitability of goods for usual } \\
\text { operations running, as an in- } \\
\text { cident of the sale, in favour } \\
\text { of reasonably contemplated } \\
\text { users (e.g. buyer's wife, mem- } \\
\text { bers of his family, etc.) Hen- } \\
\text { ningsen v. Bloomfield Mo- } \\
\text { tors.4 In U.S. there are cases } \\
\text { Also: In U.S. } \\
\text { founding liability on war- } \\
\text { ranty arising from advertise- } \\
\text { ments-an extension of the old } \\
\text { Carbolic Smoke Bomb case, } \\
\text { see: Randy Knitwear Inc. v. } \\
\text { American Cyanamic Co.5 } \\
\text { (These case developments lead } \\
\text { U.S. writers to speak of a } \\
\text { products liability independ- } \\
\text { ently of contract and tort in } \\
\text { traditional sense). } \\
\text { A similar Canadian develop- } \\
\text { ment occurs in Traders Fi- } \\
\text { nance v. Haley; Haley v. Ford } \\
\text { Motor Co.s where, owing to } \\
\text { direct sales dealings between } \\
\text { manufacturer's representative } \\
\text { and purchaser of car, man- } \\
\text { ufacturer held to be a seller } \\
\text { and subject to implied con- } \\
\text { ditions and warranties of Sale } \\
\text { of Goods Act. } \\
\text { As to "guarantees", see I be- } \\
\text { low. }\end{array}$ & $\begin{array}{l}\text { Canadian cases show a read- } \\
\text { iness on part of courts to find } \\
\text { manufacturers liable for neg- } \\
\text { ligence. For example: Fill- } \\
\text { more's Valley Nurseries Ltd. } \\
\text { v. North American Cyanamid } \\
\text { Ltd.7 failure to test a weed } \\
\text { killer. Ruegger v. Shell Oil } \\
\text { Co. failure to provide a qual- } \\
\text { ified sales agency to advise on } \\
\text { use of chemical crop sprayer. } \\
\text { Western Processing and Cold } \\
\text { Storage v. Hamilton failure } \\
\text { to test product failure to } \\
\text { provide product fit for pur- } \\
\text { poses for which sold: Algoma } \\
\text { Truck and Tractor Sales Ltd. } \\
\text { v. Bert's Auto Supply' fail- } \\
\text { ure to provide merchantable } \\
\text { product, negligence inferred. }\end{array}$ \\
\hline $\begin{array}{l}\text { F. I(4) + } \\
\text { II (1) + } \\
\text { II (3) (a) } \\
\text { (consumer, } \\
\text { defective product, } \\
\text { wants damages } \\
\text { for reduced } \\
\text { value of } \\
\text { product) }\end{array}$ & No privity of contract. & $\begin{array}{l}\text { May be applicable, see E, } \\
\text { above. }\end{array}$ \\
\hline
\end{tabular}

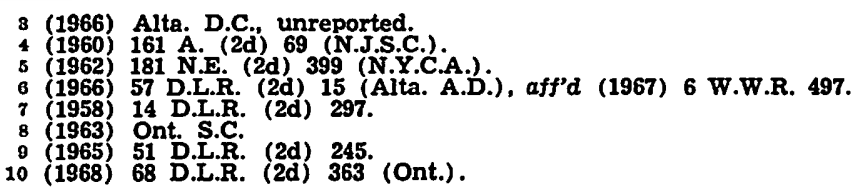




\begin{tabular}{|c|c|c|}
\hline Items & Contract & Tort \\
\hline $\begin{array}{l}\text { G. I (4) + } \\
\text { II }(2)+ \\
\text { III }(3) \\
\text { (consumer or } \\
\text { bystander, } \\
\text { defective } \\
\text { product, } \\
\text { consequential } \\
\text { loss, personal } \\
\text { injury wants } \\
\text { damages) }\end{array}$ & $\begin{array}{l}\text { No privity of contract. Pos- } \\
\text { sibility of warranty arising out } \\
\text { of advertising or sale between } \\
\text { manufacturer and related par- } \\
\text { ty, i.e. head of family, etc., } \\
\text { see E, above. }\end{array}$ & $\begin{array}{l}\text { Donaghue v. Stevenson. Lia- } \\
\text { bility based on breach of duty } \\
\text { of care in manufacturing, } \\
\text { packaging, etc. Readiness of } \\
\text { court to infer negligence from } \\
\text { fact of injury, Grant v. Aus- } \\
\text { tralian Knitting Mills.11 }\end{array}$ \\
\hline $\begin{array}{l}\text { H. I(1) (2) + } \\
\text { II (2) + } \\
\text { III (2) } \\
\text { Purchaser } \\
\text { for use or } \\
\text { defective goods, } \\
\text { resale, } \\
\text { seeking repair } \\
\text { or replacement }\end{array}$ & $\begin{array}{l}\text { Claim based on sales contract } \\
\text { and Sale of Goods Act-man- } \\
\text { ufacturer's "guarantee" prob- } \\
\text { ably will be treated as part of } \\
\text { or incorporated in sales con- } \\
\text { tract. }\end{array}$ & NA \\
\hline $\begin{array}{l}\text { I. I (3) }+ \\
\text { II }(2)+ \\
\text { III }(2) \\
\text { Remote } \\
\text { purchaser } \\
\text { defective goods, } \\
\text { seeking repair } \\
\text { or replacement }\end{array}$ & $\begin{array}{l}\text { Claim must be based on } \\
\text { establishing "guarantee" of } \\
\text { manufacturer as a contract. } \\
\text { Difficulties relate to estab- } \\
\text { lishing privity of contract and } \\
\text { consideration, especially where } \\
\text { purchaser is unaware of fact } \\
\text { of "guarantee" until after he } \\
\text { has made his purchase from } \\
\text { retailer.12 Where "guarantee" } \\
\text { requires purchaser to detach } \\
\text { and mail a card giving date } \\
\text { and place of purchase, then } \\
\text { act of mailing may be ade- } \\
\text { quate consideration to support } \\
\text { the contract. }\end{array}$ & $\mathbf{N A}$ \\
\hline $\begin{array}{l}\text { J. I(1) (2) + } \\
\text { II (1) + } \\
\text { III(4) } \\
\text { Purchaser for } \\
\text { use or resale, } \\
\text { non-delivery } \\
\text { or defective } \\
\text { goods, wants } \\
\text { relief from } \\
\text { financing } \\
\text { obligations. }\end{array}$ & $\begin{array}{l}\text { Manufacturer usually paid out } \\
\text { with financing arranged at } \\
\text { dealer level. If there are time } \\
\text { payments to manufacturer } \\
\text { and these are discounted by } \\
\text { assignment to financing agen- } \\
\text { cy, then probably no relief } \\
\text { from financing obligations ow- } \\
\text { ing to holder in due course } \\
\text { doctrine. If purchaser is a } \\
\text { consumer buying directly from } \\
\text { manufacturer then court sym- } \\
\text { pathetic to attack on status of } \\
\text { financing agency as holder in } \\
\text { due course, particularly if } \\
\text { there is tie-up between finan- } \\
\text { cial agency and manufacturer, } \\
\text { see the St. Pierre Case.13 }\end{array}$ & NA \\
\hline
\end{tabular}

\footnotetext{
11 [1936] A.C. 85.

12 See Barrie and Diamond, The Consumer, Society, and the Law, 98, 99.
}

13 (1962) 32 D.L.R. (2d) 86 . 


\section{$V$ Effects of Attempts to Exclude Liability}

Items

Contract

Tort

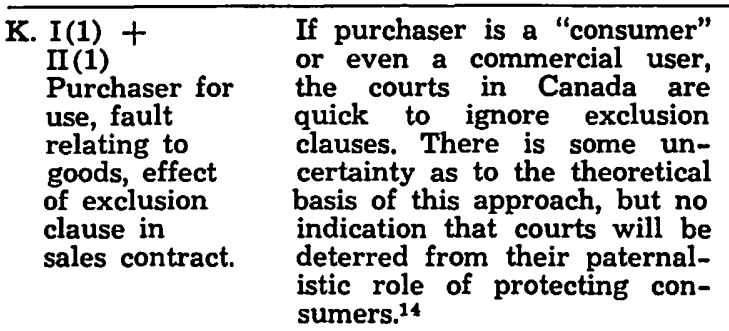

L. I(2) $+\quad$ Courts may be willing to pass

II(1)

Courts may be willing to pass

N A

Wholesaler

or dealer,

fault relating

to goods, effect

of exclusion

clauses in

wholesale or

dealer sales

contract.

\begin{tabular}{|c|c|c|}
\hline $\begin{array}{l}\text { M. I(1) (2) + } \\
\text { II (2) } \\
\text { Purchaser } \\
\text { for use or } \\
\text { wholesaler } \\
\text { or dealer, } \\
\text { consequential } \\
\text { loss, effect of } \\
\text { exclusion } \\
\text { clause in } \\
\text { sales contract. }\end{array}$ & $\begin{array}{l}\text { The consequential loss provi- } \\
\text { sion is probably the most } \\
\text { prevalent exclusion provision } \\
\text { at the level of business pur- } \\
\text { chases, being found in almost } \\
\text { all purchase order confirma- } \\
\text { tions. The Courts appear } \\
\text { ready to brush aside exclusion } \\
\text { clauses, even as to consequen- } \\
\text { tial loss, but see warning of } \\
\text { Lord Reid in Suisse Atlan- } \\
\text { tique Case, } 1 \text { where he points } \\
\text { out the obvious difference be- } \\
\text { tween the man-on-the-street } \\
\text { buyer and the sophisticated } \\
\text { commercial buyer and sees no } \\
\text { justification for a solicitous or } \\
\text { paternalistic concern for the } \\
\text { latter. The Suisse Atlantique } \\
\text { Case should caution Canadian } \\
\text { courts to exercise more re- } \\
\text { straint where consequential } \\
\text { loss is an excluded liability in } \\
\text { commercial buying and sell- } \\
\text { ing and to uphold such exclu- } \\
\text { sion at least where it operates } \\
\text { as a conscious distribution of } \\
\text { risk between commercial con- } \\
\text { cerns. }\end{array}$ & $\begin{array}{l}\text { If negligence is established } \\
\text { against the manufacturer, will } \\
\text { the exclusion clause in the } \\
\text { purchase contract protect the } \\
\text { manufacturer? It can, if ade- } \\
\text { quately worded to exclude } \\
\text { liability for negligence. }\end{array}$ \\
\hline $\begin{array}{l}\text { N. I(3) } \\
\text { Remote } \\
\text { Purchaser, } \\
\text { effect of } \\
\text { exclusion } \\
\text { clause. }\end{array}$ & $\begin{array}{l}\text { No privity of contract. If } \\
\text { privity established by, man- } \\
\text { ufacturer's "guarantee", then } \\
\text { exclusion clause contained } \\
\text { therein may be effective. But } \\
\text { it is not so easy for the man- } \\
\text { ufacturer to establish the } \\
\text { "guarantee" as a contract as it } \\
\text { is for the remote purchaser to } \\
\text { do so. }\end{array}$ & $\begin{array}{l}\text { Probably ineffective in case } \\
\text { of negligence claim, too un- } \\
\text { less contained in "guarantee" } \\
\text { which is established as a con- } \\
\text { tract between manufacturer } \\
\text { and remote purchaser. }\end{array}$ \\
\hline
\end{tabular}

14 See Fridman, The Effect of Exclusion Clauses, (1969) 7 Alta. L. Rev. 281.

15 (1958) 14 D.L.R. (2d) 297.

16 (1965) 51 D.L.R. (2d) 245 .

17 [1966] 2 All E.R. 61 .

If claim can be made on basis of negligence, exclusion clauses are equally likely to get short shrift, see Fillmore's Valley Nurseries Ltd. v. North American Cyanimid. ${ }^{15}$ or dealer to manufacturer, exclusion clause in or dealer conCold Storage Ltd. v. Hamilton Construction. ${ }^{10}$

$\mathbf{N A}$

If negligence is established Ihe manufacturer, will clause in the manufacturer? It can, if adequately worded to exclude liability for negligence.

Probably ineffective in case negligence claim, too unwhich is established as a contract between manufacturer and remote purchaser. 


\begin{tabular}{|c|c|c|}
\hline Items & Contract & Tort \\
\hline $\begin{array}{l}\text { O. I(4) } \\
\text { Consumer or } \\
\text { bystander, } \\
\text { effect of } \\
\text { exclusion } \\
\text { clause }\end{array}$ & $\begin{array}{l}\text { No privity, of contract. No } \\
\text { "guarantee". } \\
\text { In Henningsen } 18 \text { where the } \\
\text { New Jersey court found an } \\
\text { implied warranty of mer- } \\
\text { chantability running in favour } \\
\text { of the consumer, the Court } \\
\text { was also faced by exclusion } \\
\text { clauses in the manufacturer- } \\
\text { dealer-purchaser chain. It was } \\
\text { held, on the adhesion contract } \\
\text { principle, that this exclusion } \\
\text { would not prevent recovery } \\
\text { by the consumer. }\end{array}$ & No effective exclusion. \\
\hline
\end{tabular}

I began this lecture by saying that there were many indications of a fresh look at the traditional ways of classifying and dealing with commercial law problems. Much of this new approach is appearing through new legislation in the field of consumer protection. Even more significant trends appear in the case law. I can identify three major areas relating to manufacturer's liability where it seems to me that Canadian courts have overstepped traditional theoretical restraints in their desire to deal realistically with modern fact situations. One area concerns the rule of privity in contract, another, the rule of freedom of contract, and the third, the concept of negotiability. I will speak about the first two of these only.

The battleground of privity of contract has been fought over for a long time in the United States, and the Henningsen Case ${ }^{18}$ in New Jersey prompted Professor Prosser, who had written an article entitled Assault on the Citadel of Privity, ${ }^{20}$ to write another article ${ }^{21}$ in which he expressed his belief that the assault had now succeeded. After all, Henningsen had placed a virtually inescapable liability on an automobile manufacturer to a consumer based on an implied warranty of merchantability arising in the sale of the motor vehicle. The only link that was required between the consumer and the manufacturer was that the consumer be "in the distributive chain", i.e. the wife of the buyer from the dealer, or a member of the buyer's family, or someone occupying or using the car with the buyer's consent. The court didn't extend this warranty in favour of a mere bystander, because the facts of the case didn't present the issue, but it gave indications that it would not have looked unfavorably on doing so. To stretch the chain so far and still speak of "privity of contract" is to denude the phrase of meaningand so the view is prevalent in the United States that Henningsen either stands for a grey area between contract and tort, which must be treated as a new classification, or presents us with new and more elastic concepts of contract and tort.

Canadian cases as yet fall short of the reach of American cases like Henningsen, but the same trend is evidenced. In Haley v. Ford Motor Co., ${ }^{22}$ Mr. Justice Johnson was certainly pressing beyond contract dogma to the realities of modern business, when he said

"Where, as here, a purchaser goes to a manufacturer, makes known the purpose

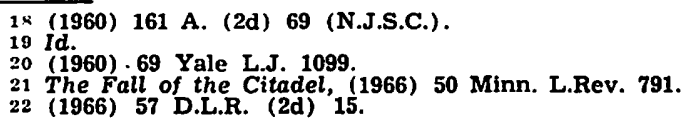


for which he requires equipment, is told that specific pieces of equipment shown to him would do the required job, then, notwithstanding who may be the parties to the ultimate agreement of sale, the manufacturer is in my opinion, the seller within the Sale of Goods Act."

The grey area between contract and tort is being invaded from the tort side as well as from the contract side. In most cases today, one could sue a manufacturer in both contract and tort. Judge Haddad, in Smith v. Fort Motor Co. ${ }^{23}$ did apply the strict rule of privity to hold that a car buyer couldn't sue a manufacturer on a dealer's new car warranty because of want of privity of contract, but he hued to the line only reluctantly, and there is some indication that he thought an action against the manufacturer based on negligence would have succeeded. We are all used to the idea that the same fact situation may give rise to claims both in contract and in tort. But when these remedies become interchangeable, we must suspect that some new concept has emerged. Claims against manufacturers in tort are based on negligence, and traditionally the requirements of duty of care and breach of that duty mark off liability in negligence from liability in contract. If these requirements merge with the requirements of obligation and breach of oblgation in contract, then either our concept of negligence has radically changed, our contract theory has changed, or there has emerged a new category in the field of manufacturer's liability. Canadian cases show that tort and contract requirements are merging in this field.

In Algoma Truck and Tractor Sales Ltd. v. Bert's Auto Supply ${ }^{24}$ an Ontario District Court Judge held that supply of a defective cylinder head by a manufacturer (reconditioner) was actionable as negligence by a remote purchaser who suffered loss of profit through using it. The duty of the manufacturer, it seems, was to supply merchantable goods, and the Judge said that breach of the duty could be inferred against the manufacturer once the remote purchaser proved that the defect could not have invaded the goods after their supply to him. It must surely be accepted that the plaintiff in this case succeeded in negligence on making proof of exactly the same two requirements that a buyer would have had to prove to establish breach of a contract of sale, namely, an implied warranty of merchantability and defective goods.

Another Canadian case, Western Processing and Cold Storage Ltd. v. Hamilton Construction ${ }^{25}$ reveals the Manitoba Court of Appeal taking another step towards blurring the differences between contract and tort. In this case the Court found a manufacturer liable for negligence to a remote purchase for breach of a duty to supply a product suitable for the purpose for which the manufacturer offered it in his catalogue. There was nothing defective about the product, but it didn't work as an insulating material for a cold-storage plant, and the manufacturer's sales literature held it out as suitable for this purpose. Again we find a plaintiff succeeding against the manufacture in negligence by proving the same requirements that he would have had to prove were he suing as a buyer claiming damages for breach of a contract of sale, namely, breach of an implied warranty of fitness for purpose.

23 (1966) Alta. D.C., unreported.

24 (1968) 68 D.L.R. (2d) 363.

25 (1965) 51 D.L.R. (2d) 245 . 
I don't regard these cases as aberrations, but as exhibiting a vigorous trend of current cases in suits against manufacturers. Whether approached from the side of an implied warranty in contract stretched to the extent of the distributive chain, as in the Henningsen Case, ${ }^{20}$ or approached from the side of a duty in tort exactly similar to the implied warranties in a sales contract, the trend is clearly to fix a manufacturer with liability to anyone suffering loss by reason of supply of a defective product or one that does not serve the purposes for which it has been placed on the market. As a practising lawyer, it may not matter much whether the theoretical development is the broadening or merging of the concepts of contract and tort, or the emergence of a new manufacturer's or products liability, so long as one is aware that there are good and persuasive precedents encouraging one to argue his client's case beyond the traditional confines of contract and tort.

My second area of change concerned freedom of contract. It would take more time than is available to review the extent to which freedom of contract is giving place to a concept of reasonableness of terms in the field of commercial contracts. The focus of this trend is the exception clause, and this subject has received a good deal of comment in recent legal periodicals. The last Alberta Law Review contains an article by Professor Fridman which will bring one up-to-date on the English developments. ${ }^{27}$ In my opinion, the decision of the House of Lords in the Suisse Atlantique Case ${ }^{28}$ has arrested any further development of the fundamental breach doctrine of Lord Denning, which was readily grasped by Canadian Courts as a theoretical underpinning for ignoring exception clauses. The House of Lords has restored construction of the contract as the theoretical basis for refusing to let manufacturers (as well as others) hide behind exception clauses. But construction is as malleable a technique as fundamental breach was a murky doctrine, and courts are still likely to ignore standardized exception clauses unless they have a reasonable and practical role to play in the commercial circumstances.

May I conclude by saying that, while I believe in the need for efficent law reform through statutory procedures, I also believe that practising lawyers and judges have as dynamic a role to play in the reform of the law through the cases as they ever did, and probably greater achievements to earn than the process of legislative reform can ever gain. May I also express the belief that, contrary to much popular sentiment, the consumer is really quite well off so far as the doctrinal aspects of the law are concerned. Where the serious defects appear, in my opinion, are in the procedural aspects, for it will be true, even after civil legal aid is flourishing, that very few consumers will be able to assert the doctrinal rights that the law affords through the ordinary process of litigation with its high risks and costs. Hence I'm sympathetic to new institutional approaches to consumer protection such as the establishment of consumer affairs departments empowered to take steps, including court action, on behalf of consumers.

$20(1960) 161$ A. 2d 69 (N.J.S.C.)

27 Fridman, The Effect of Exclusion Clauses, (1969) 7 Alta. L.Rev. 281.

28 [1966] 2 All E.R. 61 . 